\title{
Effect of plasma exchange in acute respiratory failure due to Anti-neutrophil cytoplasmic antibody-associated vasculitis
}

\author{
Guillaume Geri ${ }^{1,2^{*}} \mathbb{D}$, Benjamin Terrier ${ }^{2,3}$, Farhad Heshmati ${ }^{3}$, Hanafi Moussaoui ${ }^{3}$, Julien Massot ${ }^{1}$, Jean-Paul Mira ${ }^{1,2}$, \\ Luc Mouthon ${ }^{2,3}$ and Frédéric Pène $e^{1,2}$
}

\begin{abstract}
Background: Acute respiratory failure related to diffuse alveolar hemorrhage (DAH) is a typical presentation of small-vessel vasculitis that requires prompt multidisciplinary management. The primary treatment is based on immunosuppressive drugs, whereas urgent plasma exchange has been proposed in case of life-threatening complications. We addressed the course of respiratory failure in 12 patients with ANCA-associated vasculitisrelated DAH.
\end{abstract}

Patients and methods: Observational retrospective case series performed in the medical ICU of a tertiary hospital in Paris, France. Consecutive patients with ANCA-associated DAH admitted to our ICU for acute respiratory failure and treated by plasmapheresis were included in the analysis. We evaluated the $\mathrm{SpO}_{2} / \mathrm{FiO}_{2}$ ratio and assessed the mechanical ventilation mode hourly for 7 days.

Results: Twelve patients were included. Five of them required invasive mechanical ventilation. All patients were treated by plasma exchange in addition to a combination of glucocorticoids and immunosuppressive agents. Oxygenation improved over the first 7 days following initiation of plasma exchange, as shown by a dramatic increase in the median $\mathrm{SpO}_{2} / \mathrm{FiO}_{2}$ ratio from 183 [interquartile 137-321] to 353 [239-432] $(p=0.003)$ , along with a decrease in the level of ventilatory support. All but one patient survived.

Conclusions: A multimodal induction regimen combining immunosuppressants and plasma exchange may rapidly reverse the respiratory dysfunction in ANCA-associated vasculitis-related DAH.

Besides infectious complications, severe acute flares of ANCA-associated vasculitis are common reasons that warrant ICU admission [1]. Plasma exchange (PLEX) has been proposed as an urgent adjuvant treatment in patients with life-threatening organ dysfunctions [2, 3]. In order to explore this question, we conducted a retrospective monocenter study in our tertiary ICU. We included patients admitted to the ICU for acute respiratory failure related to $\mathrm{DAH}$, diagnosed as ANCA-associated vasculitis, and who received urgent initiation of PLEX. DAH was defined by bilateral infiltrates on chest X-ray and macroscopically bloody

\footnotetext{
* Correspondence: guillaume.geri@aphp.fr

${ }^{1}$ Medical Intensive Care Unit, Cochin Hospital, Assistance Publique-Hôpitaux de Paris, Paris, France

${ }^{2}$ Paris Descartes University, Paris, France

Full list of author information is available at the end of the article
}

bronchoalveolar lavage with hemorrhagic and siderophagic alveoliitis. PLEX was performed daily with 1.2 plasma volume plasmapheresis primarily substituted with fresh frozen plasma and then albumin 5\% and fresh frozen plasma when needed to maintain a prothrombin time $>50 \%$ and a fibrinogen level $>1.5 \mathrm{~g} / \mathrm{L}$. The main outcome was the evolution of oxygenation over the first seven days, using the $\mathrm{SpO}_{2} / \mathrm{FiO}_{2}$ ratio. We present data as median [interquartile range] or number (percentage) as appropriate. $P$ for trend for continuous variables was calculated using a Cuzick test.

Between 2006 and 2014, 12 patients were treated by PLEX in the ICU for ANCA-vasculitis with respiratory symptoms (Table 1). All patients received high-dose corticosteroids $\quad(\geq \quad 1 \mathrm{mg} / \mathrm{kg}$ prednisone-equivalent) and additional immunosuppressive drugs, either cyclophosphamide (nine within

(c) The Author(s). 2018 Open Access This article is distributed under the terms of the Creative Commons Attribution 4.0 International License (http://creativecommons.org/licenses/by/4.0/), which permits unrestricted use, distribution, and reproduction in any medium, provided you give appropriate credit to the original author(s) and the source, provide a link to the Creative Commons license, and indicate if changes were made. The Creative Commons Public Domain Dedication waiver (http://creativecommons.org/publicdomain/zero/1.0/) applies to the data made available in this article, unless otherwise stated. 
Table 1 Characteristics of patients

\begin{tabular}{|c|c|}
\hline \multirow[t]{2}{*}{ Variable } & All patients \\
\hline & $n=12$ \\
\hline Female gender & $7(58)$ \\
\hline Age (years) & $62.1[49.3-71.6]$ \\
\hline \multicolumn{2}{|l|}{ Small-vessel vasculitis } \\
\hline Granulomatosis with polyangiitis & $9(75)$ \\
\hline Microscopic polyangiitis & $3(25)$ \\
\hline Vasculitis flare as first manifestation of the disease & $11(92)$ \\
\hline \multicolumn{2}{|l|}{ Previous maintenance treatments } \\
\hline Corticosteroids & $2(16)$ \\
\hline Immunosuppressants & $6(50)$ \\
\hline \multicolumn{2}{|l|}{ Organ involvement at ICU admission } \\
\hline Pneumo-renal syndrome & $9(75)$ \\
\hline Respiratory SOFA component & $3[2-4]$ \\
\hline $\mathrm{PaO}_{2} / \mathrm{FiO}_{2}$ ratio & $154[61-386]$ \\
\hline $\mathrm{PaCO}_{2}(\mathrm{mmHg})$ & $35[31-46]$ \\
\hline Acute kidney injury requiring RRT & $5(42)$ \\
\hline Renal SOFA component & $2[1-4]$ \\
\hline Blood creatinine level $(\mu \mathrm{mol} / \mathrm{L})$ & $222[94-450]$ \\
\hline Roteinuria (g/24 h) & $1.5[1.5-3]$ \\
\hline Hemoglobin level (g/dL) & $10.1[8.2-10.7]$ \\
\hline \multicolumn{2}{|l|}{ Therapeutics received in the ICU } \\
\hline Number of plasmapheresis courses & $6[4-7]$ \\
\hline Corticosteroids & $12(100)$ \\
\hline Immunosuppressants & $12(100)$ \\
\hline Invasive mechanical ventilation & $5(42)$ \\
\hline ICU length of stay (days) $)^{a}$ & $11[7-15]$ \\
\hline In-ICU mortality & $1(8)$ \\
\hline
\end{tabular}

Continuous and categorical variables are described as median [interquartile range] and number (percentage), respectively

${ }^{a}$ In-ICU length of stay in patients with and without mechanical invasive ventilation were 15 [9-17] and 7 [4-12] days, respectively $(p=0.03)$

$R R T$ renal replacement therapy, SOFA sequential organ failure assessment

$24 \mathrm{~h}$ before or after ICU admission and one after ICU discharge) or rituximab administrated in the ICU ( $n$ $=2$ ). One patient died from refractory multiple organ failure related to septic shock. Invasive mechanical ventilation was required in five patients (two received high-frequency oscillation ventilation). One patient received adjuvant nitric oxide. Duration of invasive mechanical ventilation ranged from 6 to 20 days. Three patients successfully received non-invasive ventilation. Oxygenation improved over the first week, as shown by the increase in the $\mathrm{SpO}_{2} / \mathrm{FiO}_{2}$ ratio from $183[137-321]$ to 353 [239-432] ( $p$ value for trend $0.003)$, along with a decrease in the level of ventilatory support (Fig. 1). In contrast, only one out of five patients could be weaned off dialysis.

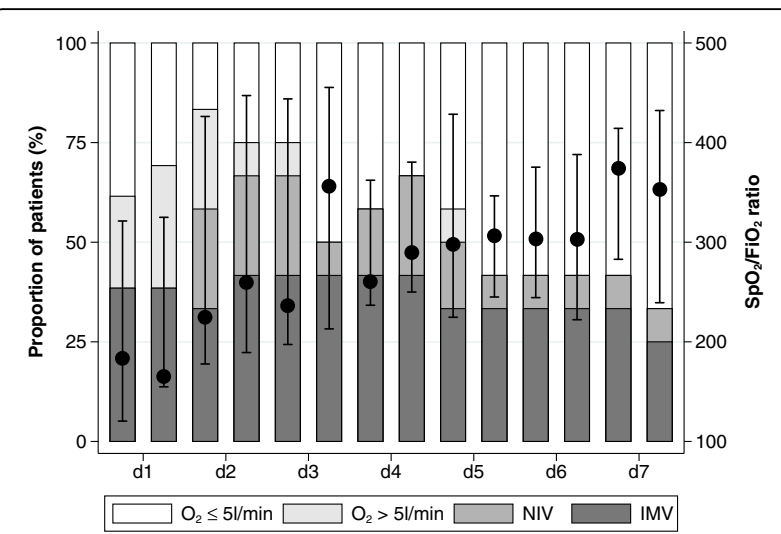

Fig. 1 Evolution of respiratory dysfunction as assessed every $12 \mathrm{~h}$ over the first 7 days ( $d 1$ to $d 7$ ) from initiation of plasma exchange. Black dots and lines represent the $\mathrm{SpO}_{2} / \mathrm{FiO}_{2}$ ratio (median and interquartile range). Background histograms show the distribution of ventilatory support. NIV non-invasive ventilation, IMV invasive mechanical ventilation

In conclusion, this suggests the addition of PLEX results in fast respiratory recovery in most patients. This contrasts with the limited impact on renal function. The effects of PLEX are presumably related to fast removal of auto-antibodies as well as pro-inflammatory mediators likely to induce and/or sustain the increased permeability of the alveolo-capillar barrier.

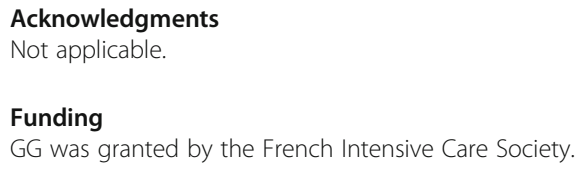

\section{Authors' contributions}

GG and FP designed the study. GG, FH, HM, and JM collected the data. GG performed the statistical analysis. GG and FP drafted the manuscript. BT, JPM, and LM critically revised the manuscript. All authors read and approved the final manuscript.

\section{Ethics approval and consent to participate}

The patients included in the study were not opposed to the anonymous use of collected data for research purposes.

\section{Consent for publication}

Not applicable.

\section{Competing interests}

The authors declare that they have no competing interests.

\section{Publisher's Note}

Springer Nature remains neutral with regard to jurisdictional claims in published maps and institutional affiliations.

\section{Author details}

${ }^{1}$ Medical Intensive Care Unit, Cochin Hospital, Assistance Publique-Hôpitaux de Paris, Paris, France. ${ }^{2}$ Paris Descartes University, Paris, France. ${ }^{3}$ Department 
of Internal Medicine, Cochin Hospital, Assistance Publique-Hôpitaux de Paris, Paris, France.

Received: 2 November 2018 Accepted: 15 November 2018

Published online: 04 December 2018

\section{References}

1. Charlier C, Henegar C, Launay O, et al. Risk factors for major infections in Wegener granulomatosis: analysis of 113 patients. Ann Rheum Dis. 2009;68:658-63.

2. Guillevin L, Lhote F, Sauvaget $F$, et al. Treatment of polyarteritis nodosa related to hepatitis B virus with interferon-alpha and plasma exchanges. Ann Rheum Dis. 1994;53:334-7 Available from: http://eutils.ncbi.nlm.nih. gov/entrez/eutils/elink.fcgi?dbfrom=pubmed\&id=7912504\&retmode= ref\&cmd=prlinks.

3. Jayne DRW, Gaskin G, Rasmussen N, et al. Randomized trial of plasma exchange or high-dosage methylprednisolone as adjunctive therapy for severe renal vasculitis. J Am Soc Nephrol. 2007;18:2180-8.

Ready to submit your research? Choose BMC and benefit from:

- fast, convenient online submission

- thorough peer review by experienced researchers in your field

- rapid publication on acceptance

- support for research data, including large and complex data types

- gold Open Access which fosters wider collaboration and increased citations

- maximum visibility for your research: over $100 \mathrm{M}$ website views per year

At $\mathrm{BMC}$, research is always in progress.

Learn more biomedcentral.com/submissions 